\title{
Oxidative stress: an evolving definition
}

\author{
Li Li Ji ${ }^{1 *}$ Dongwook Yeo ${ }^{2}$ \\ ${ }^{1}$ The Laboratory of Physiological Hygiene and Exercise Science, School of Kinesiology, University of Minnesota Twin Cities, Minneapolis, Minnesota, USA \\ ${ }^{2}$ Department of Orthopedic Surgery, Mayo Clinic, Rochester, Minnesota, USA
}

\begin{abstract}
Thirty-five years ago, Sies and colleagues insightfully described the universal phenomenon that the generation of reactive oxygen species could modify macromolecules in living organisms, resulting in a wide range of measurable damage. They used the term "oxidative stress" to define the loss of the balance between oxidants and antioxidants in favor of the former. After decades of research, it became increasingly clear that cells are not simply passive receivers of oxidative modification but can act dynamically to resist and adapt to oxidants. Furthermore, many redox-sensitive pathways have been identified wherein certain oxidants (mainly hydrogen peroxide and nitric oxide) are used as messenger molecules to transduce the signals required for these adaptations. Since the turn of the century, redox signaling has developed into a vibrant multidisciplinary field of biology. To reflect the evolution of the study in this field, the definition of oxidative stress is postulated to define a state in which the pro-oxidative processes overwhelm cellular antioxidant defense due to the disruption of redox signaling and adaptation.
\end{abstract}

\section{Keywords}

free radical, mitochondria, oxidative stress, redox signaling, skeletal muscle

\section{Peer Review}

The peer reviewers who approve this article are:

1. Zsolt Radak, Research Center for Molecular Exercise Science, University of Physical Education, Budapest, Hungary Competing interests: No competing interests were disclosed.

2. Paola Venditti, Dipartimento di Biologia, Università di Napoli Federico II, Complesso Universitario Monte Sant'Angelo, Via Cinthia, I-80126, Napoli, Italy

Competing interests: No competing interests were disclosed.

\footnotetext{
*Corresponding author: Li Li Ji (1lji@umn.edu)
}

Competing interests: The authors declare that they have no competing interests.

Grant information: The authors declare that no grants were involved in supporting this work.

Copyright: (C) $2021 \mathrm{Ji}$ LL et al. This is an open access article distributed under the terms of the Creative Commons Attribution License, which permits unrestricted use, distribution, and reproduction in any medium, provided the original work is properly cited.

How to cite this article: Ji LL and Yeo D. Oxidative stress: an evolving definition. Faculty Reviews 2021 10:(13) https://doi.org/10.12703/r/10-13 Published: 09 Feb 2021, Faculty Reviews 10:(13) https://doi.org/10.12703/r/10-13 


\section{Introduction}

Thirty-five years ago, when Sies and Cadenas ${ }^{1}$ in their landmark paper "Oxidative stress: damage to intact cells and organs" first introduced the terminology of oxidative stress, few people realized the impact of this contribution, while the definition was still a rather vague one. During the past several decades, free radical chemistry has developed far beyond a subfield of chemistry and becomes a widely known major interdisciplinary field among chemistry, biology, and medicine ${ }^{2}$. Increasing numbers of researchers have now applied the definition of oxidative stress to describe a state of disturbance, damage, and pathogenesis caused by reactive oxygen and nitrogen species (RONS) in their respective areas. Despite tremendous progress, the concept of oxidative stress is still evolving. Therefore, the purpose of this short communication is to review the historical aspects and the current status of the background of its path of evolution.

\section{Historical definition}

In their 1985 paper, Sies and Cadenas ${ }^{1}$ described a wide range of evidence wherein free radicals could be detected by various biomarkers and instrumentation and were shown to lead to cellular damage. Importantly, they pointed out that oxidative damage could result not only from external free radical insults such as irradiation and toxic chemicals but also from internal cellular mechanisms such as hydroperoxide production via normal metabolism, mono-oxygenase activation in response to xenobiotics, aldehyde formation, singlet oxygen generation, and glutathione (GSH) redox exchange ${ }^{3}$. Six years later, Sies formally gave the definition of oxidative stress as "a disturbance in the pro-oxidant-antioxidant balance in favor of the former"

Traditionally, oxidative stress has been defined by four categories of biological changes ${ }^{2}$. The first category is the detection of RONS generation in the cell. Here, RONS can be in either their radical forms (i.e. with unpaired electrons), such as superoxide, hydroxyl radicals, peroxyl radicals, and nitric oxide, or their non-radical forms, such as hydroperoxide, singlet oxygen, ozone, and peroxynitrite ${ }^{5}$. The second category describes the changes (usually the decrease) in cellular antioxidant defense capacity. This may be caused by declined abundance of low-molecular-weight antioxidants such as $\alpha$-tocopherol (vitamin E), ascorbic acid (vitamin C), GSH, and carotenoids owing to either dietary deficiency, depletion by RONS, or both. Decreased activity and/or protein content of antioxidant enzymes, such as superoxide dismutase (SOD), catalase, glutathione peroxidase (GPX), and their auxiliary enzymes such as GSH reductase (GR), glucose 6-phosphate dehydrogenase, and isocitrate dehydrogenase, can also result in oxidative stress. A number of reasons can contribute to the decline of antioxidant enzyme defense, such as gene mutation or knockout, prosthetic metal ion deficiency, drug inhibition, or simply organism aging $^{6}$. Interestingly, some organs and tissues may increase antioxidant enzyme expression to protect against RONS and thus be indicative of oxidative stress. An example is increased antioxidant enzyme activities in skeletal muscle with aging?
The third category pertains to biomarkers of oxidative stress, often termed fingerprints or footprints, reflecting the oxidative modification of a range of macromolecules. The most widely used biomarkers include lipid peroxidation (usually measured by lipid peroxide, isoprostane, 4-hydroxynonenal, and malondialdehyde), protein oxidation (measured by carbonyl formation and individual amino acid oxidative modification, such as hydroxyl- and o-tyrosine, methionine sulfoxide, and 2-oxohistidine), and DNA oxidation due to the formation of 8-hydroxyl-2'-deoxyguanosine ${ }^{5}$. Finally, a disturbance of the cellular redox status is also regarded as evidence of oxidative stress $^{1}$. Altered GSH to glutathione disulfide (GSSG) ratio and reduced-to-oxidized thioredoxin $(\mathrm{TXN})$ ratio are reliable indications of redox changes ${ }^{2}$. It is noteworthy that redox status changes are closely related to other categories of oxidative stress. For example, a surge of RONS production can overwhelm the GPX-GR cycle's reductive capacity, resulting in a rise of GSSG level with subsequent efflux from organs and tissues ${ }^{8}$. Moreover, decreased GSH/GSSG and TXN ratio can render some enzymes in the signal transduction pathways inactive, thus facilitating RONS formation and even causing redox signaling disruption (see below).

Inflammation, either acute or chronic, taking place either in the muscle cell or in the joints and soft tissues represents another form of disturbance of the balance between oxidants and antioxidants and may lead to oxidative stress ${ }^{9,10}$. Inflammation reflects the response of the organism to invading pathogens or internal damage as an adaptive protection. Initial infiltration of plasma polymorphoneutrophil (PMN) into the affected tissues can promote superoxide generation by NADPH oxidase located on PMN membrane, with subsequent production of superoxide, hydroperoxide, and hydrochloric acid to "disinfect" the damage site $^{2}$. However, excessive inflammation may be inflicted by overproduction of pro-inflammatory cytokines such as tumor necrosis factor (TNF) $\alpha$ and interleukin (IL)-1 and -6 and activating nuclear factor $(\mathrm{NF}) \kappa \mathrm{B}$ pathway ${ }^{11}$. Escalation of local inflammation due to NFKB activation can lead to elevation of plasma C-reactive protein (CRP), a liverderived protein widely regarded as a biomarker of systemic inflammation ${ }^{10}$. Chronic inflammation within muscles and ligaments after initial injury may attract PMN and macrophages to the injury sites and further enhance RONS production, forming a vicious cycle ${ }^{12}$.

Although the above categories of oxidative stress markers are widely used and effective, there are limitations in elucidating the details and nature of the cellular events. The most significant limitation of the early definition is that it somewhat implies that the biological system is a passive receiver of oxidative damage and the effects of RONS on the macromolecules are stoichiometrical $^{3}$. Research advances, especially after 1990, have gradually revealed that this is not the case. The discovery that some antioxidant enzymes can adapt to elevated reactive oxygen species (ROS) generation under various pathological, physiological (such as exercise and aging), and nutritional (such 
as certain metal ion deficiency or overload) conditions suggests that organisms can alter their internal resistance to RONS and oxidative insult to reach a new balance, i.e. oxidativeantioxidant homeostasis ${ }^{2}$. Thus, oxidative stress may mean that the system has failed to adapt to or resist the oxidants or, in the case of inflammation, has over-reacted to the initial oxidative insult. Thus, in 2006, Jones ${ }^{13}$ proposed modifying the definition of oxidative stress to "a disruption of redox signaling and control". While this proposed new concept recognizes the dynamic nature of the oxidative-antioxidant balance, it was not widely appreciated until the mechanisms by which certain ROS can serve as signaling agents to modulate the antioxidant system and even metabolic functions were fully uncovered.

\section{Role of redox signaling}

Cell signaling (also termed signal transduction) is one of the three means (other than hormones and synapsis) by which cells respond to external stimulus, via transient allosteric or covalent protein modifications or change of gene expression. Redox signaling defines a process in which cells use certain RONS as the signaling molecules for transformation and differentiation ${ }^{11}$. The role of cysteine sulfhydryl, serving as a critical moiety on the active site of glutamine synthetase, was an early example of how redox balance of a single amino acid can affect a specific cell function ${ }^{1}$. The discovery that the gene $O x y R$ could respond to the oxidative environment by expressing a particular gene product may be viewed as the simplest form of redox signaling ${ }^{14}$. Over several decades of research, it is now well established that a wide range of cellular functions including growth, adaptation, and senescence all involve redox signaling ${ }^{11}$. According to Lander $^{15}$, at least five categories of cellular responses can be stimulated by ROS, including the modulation of cytokine, growth factor, or hormone action and secretion; ion transport; transcription; neural modulation; and apoptosis. Although early research paid much attention to the role of redox changes of protein sulfhydryl in the regulation of cell function ${ }^{16}$, more recent studies indicate that nearly half of the above-mentioned effects require members of the $\mathrm{NFkB}$ and mitogen-activated protein kinase (MAPK) pathways to participate ${ }^{11}$. Furthermore, the redox regulation of protein tyrosine phosphatase (PTP) by ROS has received great attention in redox signaling ${ }^{17}$. Permanent activation of PTP due to an overwhelming reductive environment may render the enzymes bearing PTP incapable of responding to redox changes and making functional adjustments.

But why does a disturbance or loss of control of redox signaling, as suggested by Jones ${ }^{13}$, imply the occurrence of oxidative stress? First, redox signaling depends, to a large extent, on the generation and a stable concentration of RONS. Allen and Trensini ${ }^{11}$ summarized hundreds of studies in which ROS were used as signaling messengers and found that over half of the cases were conducted by $\mathrm{H}_{2} \mathrm{O}_{2}$. If the source of ROS is dramatically disturbed, redox signaling will not function properly. For example, the steady state $\mathrm{H}_{2} \mathrm{O}_{2}$ concentration in the mitochondrion is dependent on the coordinated actions of MnSOD (SOD2) and GPX; genetic deficiency or gene knockout of MnSOD can lead to superoxide spill, which reacts with $\mathrm{H}_{2} \mathrm{O}_{2}$ to produce highly reactive hydroxyl radicals, resulting in cell necrosis or death ${ }^{5}$. Conversely, an overwhelmingly reductive environment, such as an excessively high NADH/ $\mathrm{NAD}^{+}$or GSH/GSSG ratio, can also destroy redox signaling and result in "reductive stress" 18 . Second, most antioxidant enzymes contain gene regulatory sequences in their promoter and intron regions that can interact with redox-sensitive transcription factors to trigger upregulation of gene expression ${ }^{19}$. Failure to increase antioxidant defense in the face of increased oxidant production can render the cells susceptible to oxidative damage. For example, the genes of SOD2, GPX1, inducible nitric oxide synthase (iNOS), and glutamylcysteine synthetase (GCS, the rate-limiting enzyme for GSH synthesis) contain conserved sequences for $\mathrm{NF} \kappa \mathrm{B}$ binding ${ }^{11}$. Rats treated with allopurinol to supress superoxide and $\mathrm{H}_{2} \mathrm{O}_{2}$ production via xanthine oxidase were shown to fail to upregulate SOD2, iNOS, and PGC-1 $\alpha$ in response to endurance training ${ }^{20,21}$. Third, there is evidence that the decline of normal cell functions due to muscle immobilization ${ }^{22}$, diaphragm passive ventilation ${ }^{23}$, muscle ischemia ${ }^{24}$, and aging ${ }^{25}$ can also trigger oxidative stress, and a major cellular mechanism may involve the discord of redox signaling. Loss of mitochondrial homeostasis (controlled by mitochondrial biogenesis, morphological dynamics, and mitophagy) leading to increased ROS release, downregulation of antioxidant defense, and inflammation has been implicated as a potential mechanism for the disturbed redox signaling in skeletal muscle ${ }^{26,27}$. Although MAPK and NFkB are the most studied, other signaling pathways have been increasingly identified to be sensitive to redox disturbances, such as PGC- $1 \alpha^{28}$, $\mathrm{AMPK}^{29}$, FoxO family transcription factors ${ }^{30,31}$, and sirtuins ${ }^{32,33}$. In this regard, failure of proper redox signaling as a potential mechanism for aging is of particular interest to the scientific community and deserves a more extensive review ${ }^{34}$.

\section{Oxidative stress and hormesis}

Another way to define the delicate relationship between oxidative stress and redox signaling is hormesis. Hormesis is now widely recognized to be a universal phenomenon to describe an organism's response to stress, displaying a dose-response curve $^{35}$ that resembles an inverted $\mathrm{U}^{36}$. The dynamic of hormesis implies that a stress below the "breaking point" (i.e. the peak of the curve) may elicit a positive response that would make the organism more resistant to higher levels of stress. Hormetic concept has been applied to several subdisciplinary studies such as hypothermia, heat, ischemia, starvation, pro-oxidants, and other types of stress such as pain, sleeplessness, noise, cold ${ }^{37,38}$, and exercise ${ }^{39}$.

Examples that illustrate cellular adaptive response to oxidative stress are numerous. Physical exercise represents a unique 
stress that animals encounter in order to maintain mobility, seek food, and ensure reproduction and survival through rigorous muscle contraction, leading to increased ROS production ${ }^{6,40}$. Several exercise physiologists pioneered the idea that ROS might stimulate the body's antioxidant defense and either reduce ROS production or increase their removal, or both ${ }^{41}$. The discovery that $\mathrm{H}_{2} \mathrm{O}_{2}$ could induce gene expression of antioxidant enzymes via $\mathrm{NF \kappa B}$ in muscle cells provided unequivocal biochemical and molecular biological mechanisms of how such adaptations might occur ${ }^{42}$. Radak et al. ${ }^{43}$ and $\mathrm{Ji}$ et al. ${ }^{44}$ postulated that hormesis might underlie the cellular mechanism of exercise adaptation of antioxidant defense that is stimulated by ROS generation. It is now clear that while the cellular antioxidant system maintains a basal "reserve" to handle low-level oxidative challenge, most antioxidant adaptation requires de novo protein synthesis through transcription, translation, post-translational modification and protein transport ${ }^{40,45,46}$. Over the past few decades, new research has revealed that hormesis takes place in a wide range of biological activities, including but not limited to increased mitochondrial biogenesis ${ }^{26,47,48}$, change of mitochondrial morphology through fusion and fission dynamics ${ }^{49}$, and enhanced mitophagy to degrade damaged organelle $e^{50,51}$. During these hormetic responses to oxidative stress, redox signaling plays a vital role.

\section{Conclusion}

The generation of RONS is an inevitable process in aerobic life ${ }^{5}$. According to the Second Law of Thermodynamics, organisms need to obtain energy substrates from the environment to generate ATP for repair, growth, and reproduction, whereas the costs of converting nutrients to low-entropy forms for self-preservation are the production of high-entropy wastes (water, $\mathrm{CO}_{2}$, urea) and heat ${ }^{52}$. Throughout life, the balance between the oxidative process to release energy from substrates and the antioxidant defense to minimize self-destruction continues. Thus, oxidative stress is inevitable and has been postulated as the most important biological mechanism for aging ${ }^{53-55}$. Meanwhile, the definition of oxidative stress has evolved from a more descriptive term emphasizing end results to a more dynamic alternative reflecting the role of adaptive processes involving redox signaling and hormesis ${ }^{45}$. At the end of the day, the authors favor a modified definition to summarize the points of view herein: oxidative stress defines a state in which the pro-oxidative process overrides cellular antioxidant defense due to the disruption of redox signaling (Figure 1).

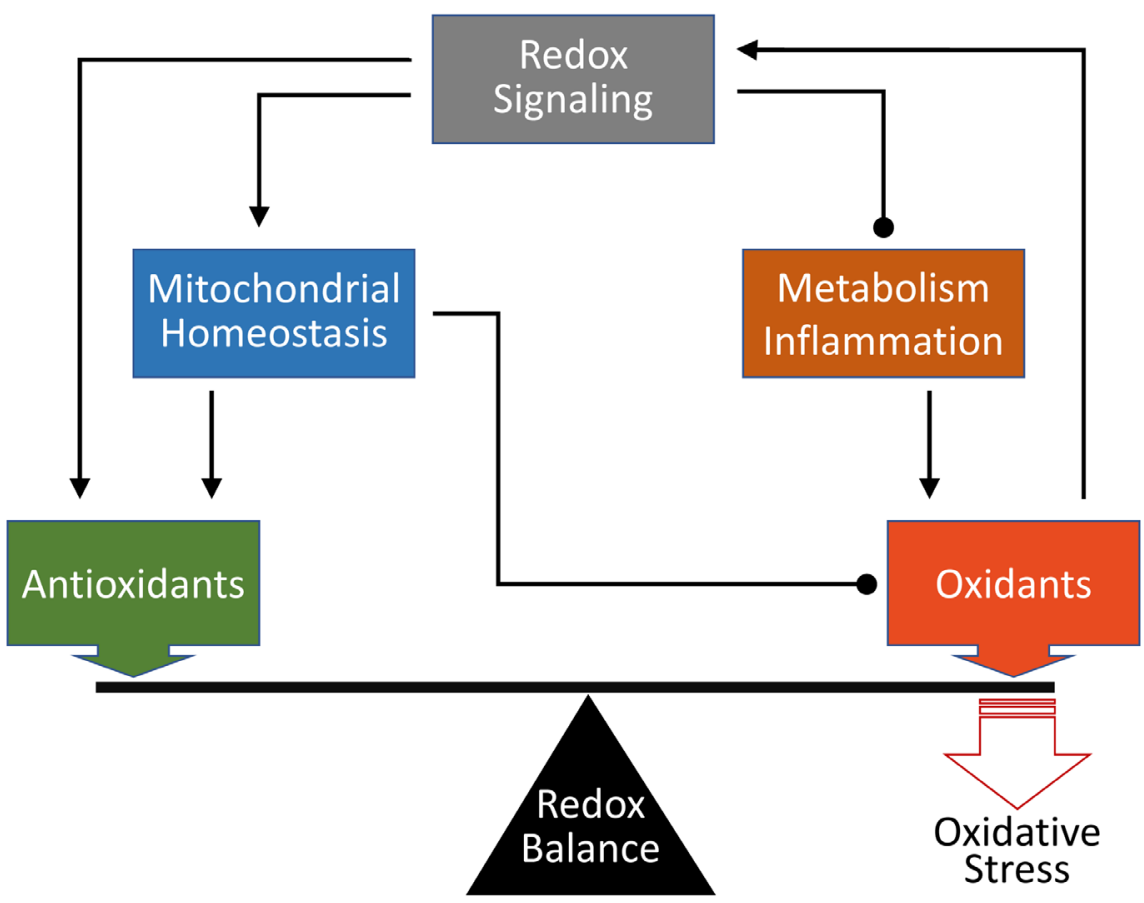

Figure 1. Schematic representation of the roles of oxidants and antioxidants in determining oxidative stress. Through redox signaling, oxidants can directly upregulate antioxidant defense or indirectly ameliorate mitochondrial homeostasis, thus reducing oxidant production. Redox signaling also modulates cellular metabolic process and inflammation to minimize oxidants. Failure or discord of redox signaling leads to a tip of oxidant-antioxidant balance in favor of the former and thus oxidative stress. Arrow-headed lines represent activation; dot-ended lines represent inhibition. 
1. Sies H, Cadenas E: Oxidative stress: Damage to intact cells and organs. Phil Trans $R$ Soc B. 1985; 311(1152): 617-31.

PubMed Abstract | Publisher Full Text

2. Powers SK, Jackson MJ: Exercise-induced oxidative stress: Cellular mechanisms and impact on muscle force production. Physiol Rev. 2008; 88(4): 1243-76.

PubMed Abstract | Publisher Full Text | Free Full Text

3. Hensley K, Floyd RA: Reactive oxygen species and protein oxidation in aging: A look back, a look ahead. Arch Biochem Biophys. 2002; 397(2): 377-83.

PubMed Abstract | Publisher Full Text

4. Sies H: Oxidative stress. London: Orlando: Academic Press; 1985; xv: 507. Publisher Full Text

5. Halliwell B, Gutteridge JMC: Free radicals in biology and medicine. 3rd ed. Oxford New York: Clarendon Press; Oxford University Press; 1999; xxxi: 936. Reference Source

6. Ji LL: Antioxidant enzyme response to exercise and aging. Med Sci Sports Exerc. 1993; 25(2): 225-31.

PubMed Abstract

7. Ji LL, Dillon D, Wu E: Alteration of antioxidant enzymes with aging in rat skeletal muscle and liver. Am J Physiol. 1990; 258(4 Pt 2): R918-23. PubMed Abstract | Publisher Full Text

8. Ji LL, Leeuwenburgh C: Exercise and glutathione. In: Somani S editor. Pharmocology in exercise and sports. Boca Raton, Florida: CRC Press; 1995; $97-123$

9. Ji LL, Kang C, Zhang Y: Exercise-induced hormesis and skeletal muscle health. Free Radic Biol Med. 2016; 98: 113-22. PubMed Abstract | Publisher Full Text

10. Arulselvan P, Fard MT, Tan WS, et al.: Role of Antioxidants and Natural Products in Inflammation. Oxid Med Cell Longev. 2016; 2016: 5276130. PubMed Abstract | Publisher Full Text | Free Full Text

11. Allen RG, Tresini M: Oxidative stress and gene regulation. Free Radic Biol Med. 2000; 28(3): 463-99. PubMed Abstract | Publisher Full Text

12. VanderVeen BN, Murphy EA, Carson JA: The Impact of Immune Cells on the Skeletal Muscle Microenvironment During Cancer Cachexia. Front Physiol. 2020; 11: 1037.

PubMed Abstract | Publisher Full Text | Free Full Text |

Faculty Opinions Recommendation

13. Jones DP: Redefining oxidative stress. Antioxid Redox Signal. 2006; 8(9-10): 1865-79.

PubMed Abstract | Publisher Full Text

14. Kim SO, Merchant K, Nudelman R, et al:: OxyR: a molecular code for redoxrelated signaling. Cell. 2002; 109(3): 383-96.

PubMed Abstract | Publisher Full Text

15. Lander HM: An essential role for free radicals and derived species in signal transduction. FASEB J. 1997; 11(2): 118-24. PubMed Abstract | Publisher Full Text

16. Abate C, Patel L, Rauscher FJ: Redox regulation of fos and jun DNA-binding activity in vitro. Science. 1990; 249(4973): 1157-61. PubMed Abstract | Publisher Full Text

17. Hecht $D$, Zick $Y$ : Selective inhibition of protein tyrosine phosphatase activities by $\mathrm{H} 2 \mathrm{O} 2$ and vanadate In vitro. Biochem Biophys Res Commun. 1992; 188(2): $773-9$.

PubMed Abstract | Publisher Full Text

18. Xiao W, Loscalzo J: Metabolic Responses to Reductive Stress. Antioxid Redox Signal. 2020; 32(18): 1330-47.

PubMed Abstract | Publisher Full Text | Free Full Text |

Faculty Opinions Recommendation

19. Ji LL: Modulation of skeletal muscle antioxidant defense by exercise: Role of redox signaling. Free Radic Biol Med. 2008; 44(2): 142-52.

PubMed Abstract | Publisher Full Text

20. Gomez-Cabrera MC, Borrás C, Pallardó FV, et al.: Decreasing xanthine oxidasemediated oxidative stress prevents useful cellular adaptations to exercise in rats. J Physiol. 2005; 567(Pt 1): 113-20. PubMed Abstract | Publisher Full Text | Free Full Text

21. Kang C, O'Moore KM, Dickman JR, et al:: Exercise activation of muscle peroxisome proliferator-activated receptor-gamma coactivator-1alpha signaling is redox sensitive. Free Radic Biol Med. 2009; 47(10): 1394-400. PubMed Abstract | Publisher Full Text

22. Ji LL, Yeo D, Kang C: Muscle Disuse Atrophy Caused by Discord of Intracellular Signaling. Antioxid Redox Signal. 2020.

PubMed Abstract | Publisher Full Text

23. Powers SK, Kavazis AN, Levine S: Prolonged mechanical ventilation alters diaphragmatic structure and function. Crit Care Med. 2009; 37(10 Suppl):
S347-53

PubMed Abstract | Publisher Full Text | Free Full Text

24. Cristina-Oliveira M, Meireles K, Spranger MD, et al: Clinical safety of blood flow-restricted training? A comprehensive review of altered muscle metaboreflex in cardiovascular disease during ischemic exercise. Am J Physio Heart Circ Physiol. 2020; 318(1): H90-H109. PubMed Abstract | Publisher Full Text | Free Full Text Faculty Opinions Recommendation

25. Kim Y, Triolo M, Hood DA: Impact of Aging and Exercise on Mitochondrial Quality Control in Skeletal Muscle. Oxid Med Cell Longev. 2017; 2017: 3165396. PubMed Abstract | Publisher Full Text | Free Full Text Faculty Opinions Recommendation

26. Hood DA, Tryon LD, Carter HN, et al:: Unravelling the mechanisms regulating muscle mitochondrial biogenesis. Biochem J. 2016; 473(15): 2295-314.

PubMed Abstract | Publisher Full Text | Faculty Opinions Recommendation

27. Ji LL, Yeo D: Mitochondrial dysregulation and muscle disuse atrophy [version 1; peer review: 2 approved]. F1000Res. 2019; 8: F1000 Faculty Rev-1621. PubMed Abstract | Publisher Full Text | Free Full Text

28. Handschin C, Chin S, Li P, et al:: Skeletal muscle fiber-type switching, exercise intolerance, and myopathy in PGC-1alpha muscle-specific knock-out animals. J Biol Chem. 2007; 282(41): 30014-21.

PubMed Abstract | Publisher Full Text | Faculty Opinions Recommendation

29. Sanchez AMJ, Candau RB, Csibi A, et al.: The role of AMP-activated protein kinase in the coordination of skeletal muscle turnover and energy homeostasis. Am J Physiol, Cell Physiol. 2012; 303(5): C475-85. PubMed Abstract | Publisher Full Text

30. Sanchez AMJ, Candau RB, Bernardi H: FoxO transcription factors: Their roles in the maintenance of skeletal muscle homeostasis. Cell Mol Life Sci. 2014; 71(9): 1657-71.

PubMed Abstract | Publisher Full Text

31. Sandri M, Lin J, Handschin C, et al:: PGC-1alpha protects skeletal muscle from atrophy by suppressing $\mathrm{FoxO} 3$ action and atrophy-specific gene transcription. Proc Natl Acad Sci U S A. 2006; 103(44): 16260-5.

PubMed Abstract | Publisher Full Text | Free Full Text

32. Michan S, Sinclair D: Sirtuins in mammals: Insights into their biological function. Biochem J. 2007; 404(1): 1-13. PubMed Abstract | Publisher Full Text | Free Full Text

33. Singh CK, Chhabra G, Ndiaye MA, et al:: The Role of Sirtuins in Antioxidant and Redox Signaling. Antioxid Redox Signal. 2018; 28(8): 643-61. PubMed Abstract | Publisher Full Text | Free Full Text | Faculty Opinions Recommendation

34. Forman $\mathrm{HJ}$ : Redox signaling: An evolution from free radicals to aging. Free Radic Biol Med. 2016; 97: 398-407. PubMed Abstract | Publisher Full Text | Free Full Text

35. Calabrese EJ, lavicoli I, Calabrese V: Hormesis: Its impact on medicine and health. Hum Exp Toxicol. 2013; 32(2): 120-52.

PubMed Abstract | Publisher Full Text

36. Reid MB: Invited Review: Redox modulation of skeletal muscle contraction: what we know and what we don't. J Appl Physiol (1985). 2001; 90(2): 724-31. PubMed Abstract | Publisher Full Text

37. Marques FZ, Markus MA, Morris BJ: Hormesis as a pro-healthy aging intervention in human beings? Dose Response 2009; 8(1): 28-33. PubMed Abstract | Publisher Full Text | Free Full Text

38. Le Bourg E: Hormesis, aging and longevity. Biochim Biophys Acta. 2009; 1790(10): 1030-9.

PubMed Abstract | Publisher Full Text

39. Peake JM, Markworth JF, Nosaka K, et al.: Modulating exercise-induced hormesis: Does less equal more? J Appl Physiol (1985). 2015; 119(3): 172-89. PubMed Abstract| Publisher Full Text

40. Sen CK, Packer L: Antioxidant and redox regulation of gene transcription. FASEB J. 1996; 10(7): 709-20. PubMed Abstract | Publisher Full Text

41. Jenkins RR, Friedland $\mathrm{R}$, Howald $\mathrm{H}$ : The relationship of oxygen uptake to superoxide dismutase and catalase activity in human skeletal muscle. Int Sports Med. 1984; 5(1): 11-4. PubMed Abstract | Publisher Full Text

42. Zhou LZH, Johnson AP, Rando TA: NFKB and AP-1 mediate transcriptiona responses to oxidative stress in skeletal muscle cells. Free Radic Biol Med. 2001; 31(11): 1405-16. PubMed Abstract | Publisher Full Text

43. Radak Z, Chung HY, Goto S: Exercise and hormesis: Oxidative stress-related adaptation for successful aging. Biogerontology. 2005; 6(1): 71-5. PubMed Abstract | Publisher Full Text 
44. Ji LL, Gomez-Cabrera MC, Vina J: Exercise and hormesis: Activation of cellular antioxidant signaling pathway. Ann N Y Acad Sci. 2006; 1067: 425-35. PubMed Abstract | Publisher Full Text

45. Sies H, Berndt C, Jones DP: Oxidative Stress. Annu Rev Biochem. 2017; 86 715-48.

PubMed Abstract | Publisher Full Text | Faculty Opinions Recommendation

46. Tonelli C, Chio IIC, Tuveson DA: Transcriptional Regulation by Nrf2. Antioxid Redox Signal. 2018; 29(17): 1727-45.

PubMed Abstract | Publisher Full Text | Free Full Text | Faculty Opinions Recommendation

47. Ji LL, Yeo D, Kang C, et al.: The role of mitochondria in redox signaling of muscle homeostasis. J Sport Health Sci. 2020; 9(5): 386-93. PubMed Abstract | Publisher Full Text | Free Full Text

48. Tanaka T, Nishimura A, Nishiyama K, et al:: Mitochondrial dynamics in exercise physiology. Pflugers Arch. 2020; 472(2): 137-153. PubMed Abstract | Publisher Full Text | Faculty Opinions Recommendation

49. Chan DC: Mitochondrial Dynamics and Its Involvement in Disease. Annu Rev Pathol. 2020; 15: 235-59. PubMed Abstract | Publisher Full Text | Faculty Opinions Recommendation

50. Mammucari C, Milan G, Romanello V, et al.: FoxO3 controls autophagy in skeletal muscle in vivo. Cell Metab. 2007; 6(6): 458-71. PubMed Abstract | Publisher Full Text

51. Sakellariou GK, Pearson T, Lightfoot AP, et al:: Mitochondrial ROS regulate oxidative damage and mitophagy but not age-related muscle fiber atrophy. $\mathrm{Sci}$ Rep. 2016; 6: 33944.

PubMed Abstract | Publisher Full Text | Free Full Text

Faculty Opinions Recommendation

52. Schreiber A, Gimbel S: Evolution and the Second Law of Thermodynamics: Effectively Communicating to Non-technicians. Evo Edu Outreach. 2010; 3(1): 99-106.

Publisher Full Text

53. Harman D: Aging: A theory based on free radical and radiation chemistry. J Gerontol. 1956; 11(3): 298-300. PubMed Abstract | Publisher Full Tex

54. Pomatto LCD, Davies KJA: Adaptive homeostasis and the free radica theory of ageing. Free Radic Biol Med. 2018; 124: 420-30.

PubMed Abstract | Publisher Full Text | Free Full Text |

Faculty Opinions Recommendation

55. Viña J, Borras C, Gomez-Cabrera MC: A free radical theory of frailty. Free Radic Biol Med. 2018; 124: 358-63.

PubMed Abstract | Publisher Full Text | Faculty Opinions Recommendation 